\title{
Growth factors in ovarian function
}

\author{
R. S. Carson, Z. Zhang, L. A. Hutchinson*, A. C. Herington and \\ J. K. Findlay
}

\begin{abstract}
Medical Research Centre, Prince Henry's Hospital, St Kilda Road, Melbourne, Victoria 3004, Australia
\end{abstract}

Keywords: ovary; granulosa; theca; growth factors

The studies of the effects of epidermal growth factor (EGF) and fibroblast growth factor (FGF) on bovine granulosa cells under chemically defined conditions in vitro first indicated that these growth factors have a role in stimulation of follicle cell proliferation (Gospodarowicz et al., 1977). Even now, however, relatively few data in respect of the mitogenic action of these growth factors on follicle cells are available and most studies have concentrated on the role of growth factors in control of functional differentiation of follicle cells. This probably reflects the technical and interpretive difficulties associated with stimulation of follicle cell mitosis under defined conditions.

It is now evident that a range of growth factors influence not only proliferation but also functional differentiation of ovarian follicle cells. The growth factors of specific interest are the insulin-like growth factor-type I (IGF-I), transforming growth factor-type $\beta$ (TGF- $\beta$ ), EGF and platelet-derived growth factor (PDGF).

\section{Growth factors in the context of follicular development}

Before ovulation is possible, the theca and granulosa cells of pre-antral and small antral follicles must undergo extensive proliferation and functional differentiation (Hsueh et al., 1984). Based on relative numbers of receptors for pituitary follicle-stimulating hormone (FSH) and luteinizing hormone ( $\mathrm{LH})$, granulosa cells of small antral follicles are thought to be primarily FSH-dependent. As follicular development proceeds, the number of LH receptors on granulosa cells is increased many fold and numbers of FSH receptors are reduced. Throughout development of the ovulatory follicle, theca cells respond to LH only (Richards et al., 1976). Although aromatase activity is present in small antral follicles, oestrogen production at this stage of development is limited by an inability to produce the androgen substrate required for aromatization to oestrogen (Carson et al., 1981). Growth beyond the small antral phase is therefore characterized by increased aromatase, androgen synthesis, and therefore follicular oestrogen production.

Functional differentiation of follicle cells during development is evident also in increased follicular production of inhibin, a follicular protein which inhibits selectively pituitary FSH secretion (Burger et al., 1988).

Increased follicular secretion of oestradiol and inhibin is not only the hallmark of developing follicles, but also a regulator of pituitary gonadotrophin secretion. Together with changes in follicular sensitivity to pituitary gonadotrophins, follicular inhibin secretion is thought to mediate selection and dominance of the few ovulatory follicles. Factors which control follicular inhibin and oestradiol secretion and mitosis of follicle cells must therefore be considered important in regulation of follicular development.

\footnotetext{
*Present address: Department of Microbiology, University of Western Australia, Nedlands, Western Australia 6009, Australia.
} 


\section{Growth factors, follicle cell differentiation and mitosis}

Serum of calf fetuses and other biological preparations which have been used traditionally for maintenance of cell growth in vitro are thought to contain a variety of mitogens and growth factors. Studies of the effects of specific growth factors on ovarian cells must therefore be conducted in defined media in the absence of sera and other 'maintenance factors'.

Our studies of the effects of exogenous growth factors on follicle cells have been based on granulosa cells isolated from the ovaries of immature female rats treated with diethylstilboestrol in vivo (Richards, 1975). These cells were maintained in McCoy's 5A medium supplemented with glutamine ( $2 \mathrm{~mm}$ ), non-essential amino acids and antibiotics. Exogenous growth factors were added as indicated below.

Aromatase activity and inhibin production were used as indicators of functional differentiation of granulosa cells after $48 \mathrm{~h}$. Aromatase activity was measured radiometrically by conversion of $\left[1,2-{ }^{3} \mathrm{H}\right]$ testosterone to oestradiol- $17 \beta$ and ${ }^{3} \mathrm{H}_{2} \mathrm{O}$. In separate experiments, inhibin content of culture media was measured by pituitary cell bioassay (Zhang et al., 1987a) or specific radioimmunoassay (McLachlan et al., 1986).

\section{IGF-I (somatomedin-C)}

Addition of IGF-I (Sm-C) either alone or together with a constant dose of FSH $(300 \mathrm{ng} / \mathrm{ml})$ to rat granulosa cells resulted in dose-dependent increases in inhibin production over $48 \mathrm{~h}$ (Fig. 1). Although the dose of FSH used had previously been shown to give maximal stimulation of inhibin production, the response to FSH was further increased at all doses of IGF-I. This could possibly be due to enhancement of FSH-induced adenylate cyclase activity (Adashi et al., 1986a), but the effects of FSH and IGF-I were not additive, which suggested that each agent acted through different cellular mechanisms (Zhang et al., 1987b).

Whereas addition of pregnant mares' serum gonadotrophin (PMSG) to cultures resulted in significant increases in both aromatase activity and progesterone production, IGF-I at doses up to $60 \mathrm{ng} / \mathrm{ml}$ was without significant effect (Fig. 2). However, when IGF-I was added at a range of doses there was a dose-dependent increase in both steroidogenic activities above that observed in the presence of PMSG alone. These findings are consistent with results of similar studies reported by Adashi et al. (1985a).

Together with the ability of IGF-I to stimulate granulosa cell oxytocin secretion (Schams et al., 1988), side-chain cleavage-P450 (Veldhuis et al., 1986), low density lipoprotein and sterol metabolism (Veldhuis \& Rogers, 1987; Veldhuis et al., 1987), and FSH-induced adenylate cyclase activity (Adashi et al., 1986a) and LH receptor induction (Adashi et al., 1985b), these data establish that IGF-I is able to modulate basal and FSH-induced granulosa cell function.

The role of IGF-I in control of granulosa cell proliferation is not clear. Although IGF-I stimulated mitosis of cattle (Savion et al., 1981) and pig (Baranao \& Hammond, 1984a) granulosa cells, no effect on rat granulosa cell number was observed in vitro (Adashi et al., 1984). IGF-I prevention of FSH-induced reduction in $\left[{ }^{3} \mathrm{H}\right]$ thymidine incorporation into rat granulosa DNA would, however, be consistent with a positive effect on rat granulosa cell mitosis (Adashi et al., 1985c).

These effects of IGF-I are presumed to be mediated directly by specific receptors for IGF-I on granulosa cells. Baranao \& Hammond (1984a) first demonstrated IGF-I binding to pig granulosa cells and IGF-I binding sites on rat granulosa cells were subsequently characterized (Davoren et al., 1986; Adashi et al., 1988a). Furthermore, IGF-I binding activity was increased by exposure of granulosa cells to FSH in vitro (Adashi et al., 1986b) and in vivo (Adashi et al., 1988b) through a cAMP-dependent mechanism (Adashi et al., 1988c).

The physiology of IGF-I in follicular development is further complicated by observations that the granulosa cell itself produces IGF-I under the action of growth hormone (Davoren \& Hsueh, 


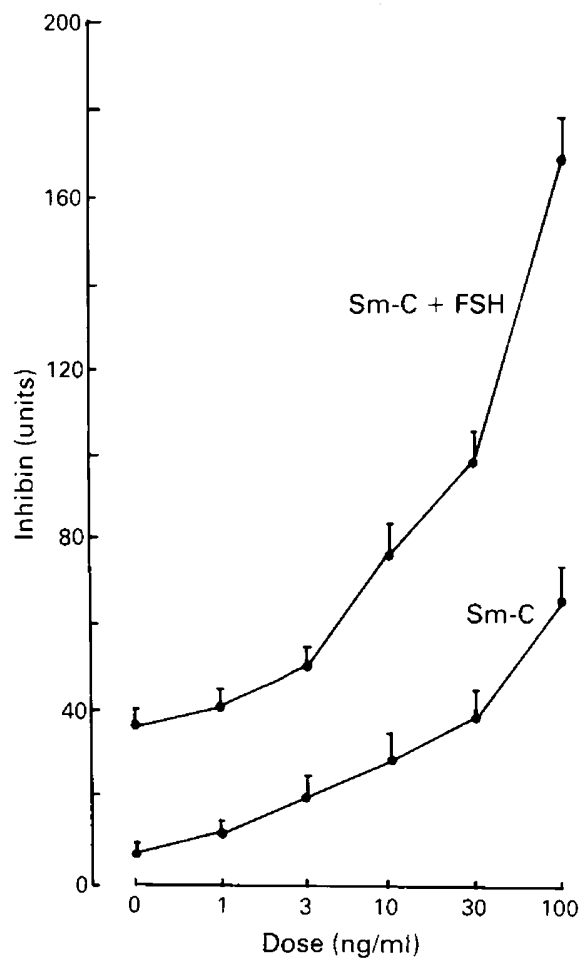

Fig. 1. Effect of IGF-I (Sm-C) on inhibin production by rat granulosa cells in vitro. Granulosa cells were isolated from diethylstilboestrol-treated immature rats and cultured for $48 \mathrm{~h}$ with IGF-I $(\mathrm{Sm}-\mathrm{C})$ alone or in combination with FSH $(100 \mathrm{ng} / \mathrm{ml})$. Values represent the mean \pm s.e. of triplicate determinations. (Reproduced from Zhang et al. 1987b.)

1986), FSH and oestradiol-17 (Hammond et al., 1985; Hsu \& Hammond, 1987) and that IGF-I is able to stimulate the thecal androgen production upon which follicular oestradiol synthesis is dependent (Hernandez et al., 1988).

IGF-I secreted by granulosa cells therefore maximizes FSH-dependent differentiation by potentiating the trophic effects of FSH on aromatase and stimulation of thecal androgen synthesis. The physiological significance of this role for IGF-I is emphasized by the apparent ability of FSH to maintain responsiveness to IGF-I through increased IGF-I receptor activity.

\section{Transforming growth factor-type $\beta$ (TGF- $\beta$ ), inhibin and activin}

As with IGF-I, TGF- $\beta$ is seen also to have a positive effect on granulosa cell differentiation in vitro. FSH-dependent induction of granulosa receptors for both LH (Knecht et al., 1986; Dodson \& Schomberg, 1987) and EGF (Feng et al., 1986) are potentiated by TGF- $\beta$ in vitro. While TGF- $\beta$ at concentrations up to $16 \mathrm{pM}$ did not alter significantly basal aromatase or progesterone synthesis in rat granulosa cells, FSH-induced aromatase activity was enhanced in a dose-dependent manner (Hutchinson et al., 1987; Fig. 3). In similar experiments, Ying et al. (1986) also reported an enhancement of FSH-induced aromatase in rat granulosa cells in vitro. The positive effect of TGF- $\beta$ on granulosa cell differentiation was not limited to enhancement of FSH-induced activity; inhibin production was significantly greater than control (no exogenous hormones) when TGF- $\beta$ was added to cultures of granulosa cells at a concentration of $1 \mathrm{ng} / \mathrm{ml}$ (Fig. 4). Addition of both FSH $(1 \mathrm{ng} / \mathrm{ml})$ and TGF- $\beta(1 \mathrm{ng} / \mathrm{ml})$ resulted in inhibin production which exceeded the sum of that 


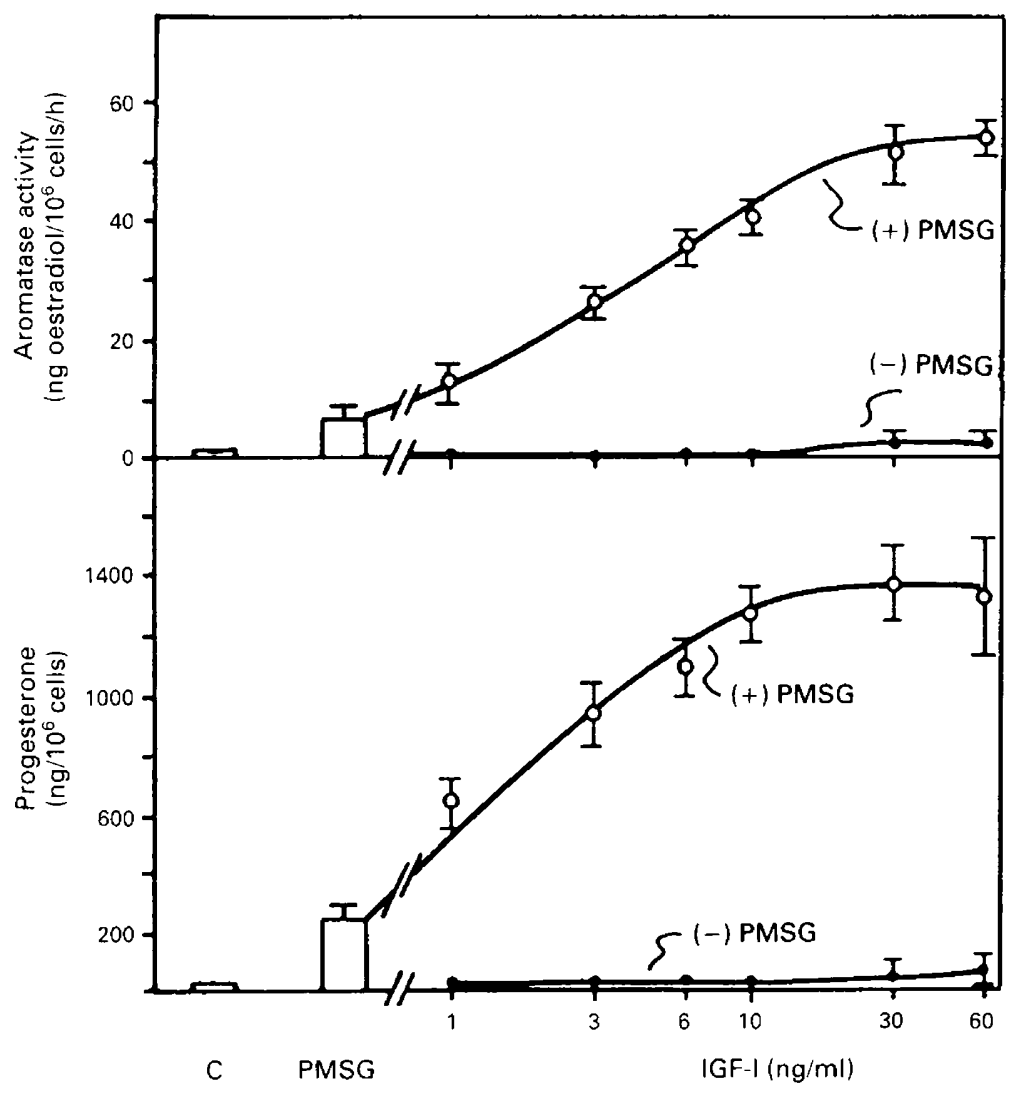

Fig. 2. Effect of IGF-I on basal and PMSG-induced aromatase activity and progesterone production by rat granulosa cells in vitro. Cells were cultured for 3 days with IGF-I in the presence or absence of PMSG $(100 \mathrm{mU} / \mathrm{ml})$. Values represent the mean \pm s.d. of triplicate cultures. (Reproduced from Hutchinson et al., 1987.)

produced in the presence of either hormone alone, suggesting that the effect of each hormone was mediated by distinct mechanisms (Zhang et al., 1988).

Although TGF- $\beta$ stimulates proliferation of mesenchymal cells, TGF- $\beta$ inhibits mitosis of EGF-responsive epithelial cells (Moses et al., 1985). Granulosa cells are of an epithelial cell type which responds to EGF with increased mitotic activity (Gospodarowicz et al., 1977) and to TGF- $\beta$ with reduced mitosis (Skinner et al., 1987a). A preliminary report that expression of the TGF- $\beta$ gene by ovarian tissue is stimulated up to 4-fold by FSH (Hernandez et al., 1987) further suggests that ovarian TGF- $\beta$ has a positive effect on follicular development by maximizing follicular responses to the trophic action of FSH and inhibition of EGF-induced mitosis.

The subunit which constitutes the homodimer which is TGF- $\beta$ (Mason et al., 1985) exhibits sufficient structural homology with the B-subunit of inhibin to indicate that TGF- $\beta$, inhibin and related dimers are products of the same family of genes (Tsonis \& Sharpe, 1986, for review). As with TGF- $\beta$, inhibin and dimers of the inhibin B-subunit are also able to modulate granulosa and theca cell function in vitro.

While activin (the homodimer of the inhibin B-subunit) augments granulosa cell aromatase activity and inhibits FSH-induced progesterone synthesis (Hutchinson et al., 1987), inhibin has no significant effect on basal or FSH-induced aromatase activity and progesterone synthesis at doses 


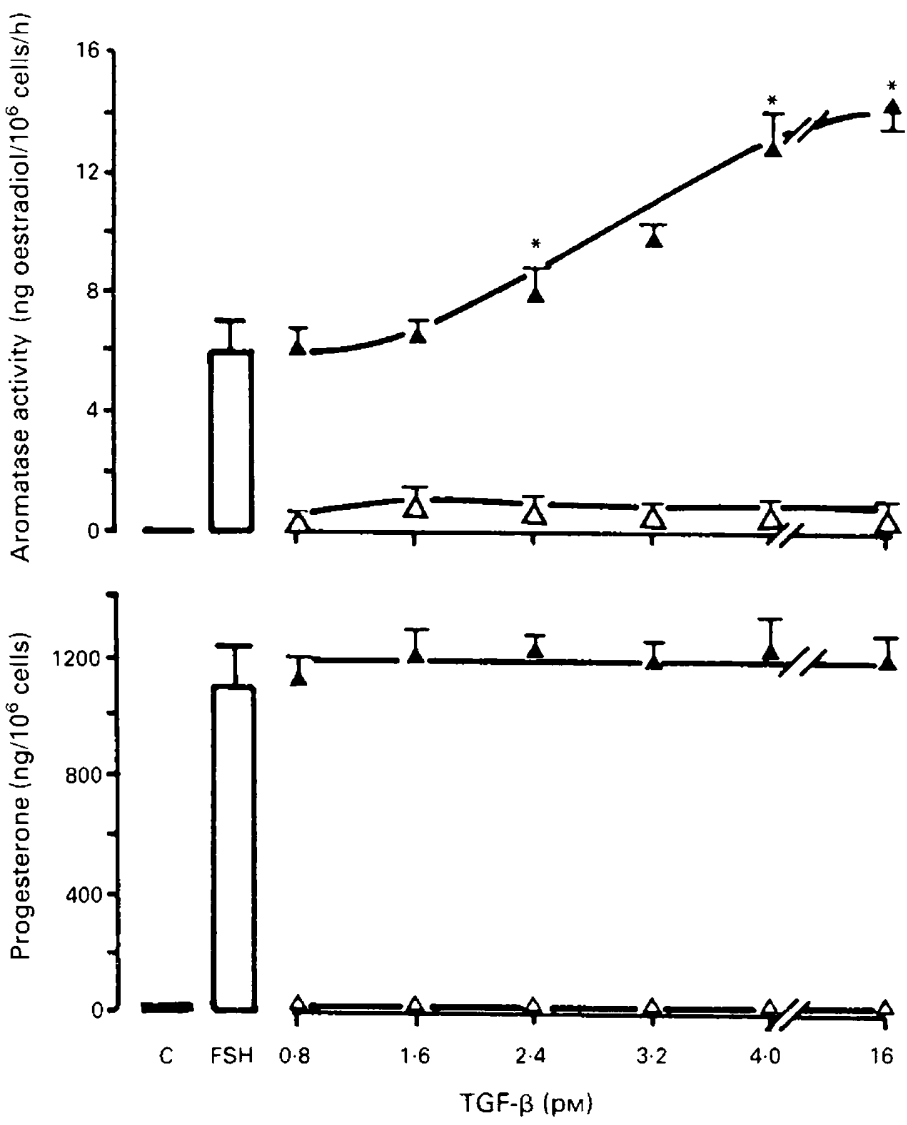

Fig. 3. Effect of TGF- $\beta$ on aromatase activity and progesterone production by rat granulosa cells in vitro. Cells were cultured for 3 days with TGF- $\beta$ in the absence (open symbols) or presence of FSH $(50 \mathrm{ng} / \mathrm{ml}$; solid symbols). Values represent the mean \pm s.d. of triplicate cultures. (Reproduced from Hutchinson et al., 1987.)

up to $4 \mathrm{pm}$ (Hutchinson et al., 1987). Ying et al. (1986) report an inhibition of FSH-induced aromatase in the presence of inhibin at higher doses.

Basal androstenedione secretion by theca cells was not altered significantly by inhibin or activin in vitro (Hsueh et al., 1987). Exogenous LH did result in a dose-dependent increase in androstenedione secretion and this was further enhanced by simultaneous addition of inhibin (1-30 $\mathrm{ng} / \mathrm{ml})$. Addition of activin resulted in a dose-dependent suppression of LH-induced androstenedione secretion (Hsueh et al., 1987).

TGF- $\beta$, inhibin and activin are therefore products of the same gene family and have both positive and negative effects on FSH-dependent granulosa cell function and LH-dependent androstenedione production by theca cells.

\section{Epidermal growth factor ( $E G F$ )}

Whereas IGF-I and TGF- $\beta$ enhance granulosa cell differentiation in vitro, EGF is generally inhibitory. EGF inhibits basal inhibin secretion as well as FSH-, 8-bromo-cAMP- and prostaglandin $\mathrm{E}_{2}$-induced inhibin secretion by rat granulosa cells in vitro (Zhang et al., 1987a) (Fig. 5). 


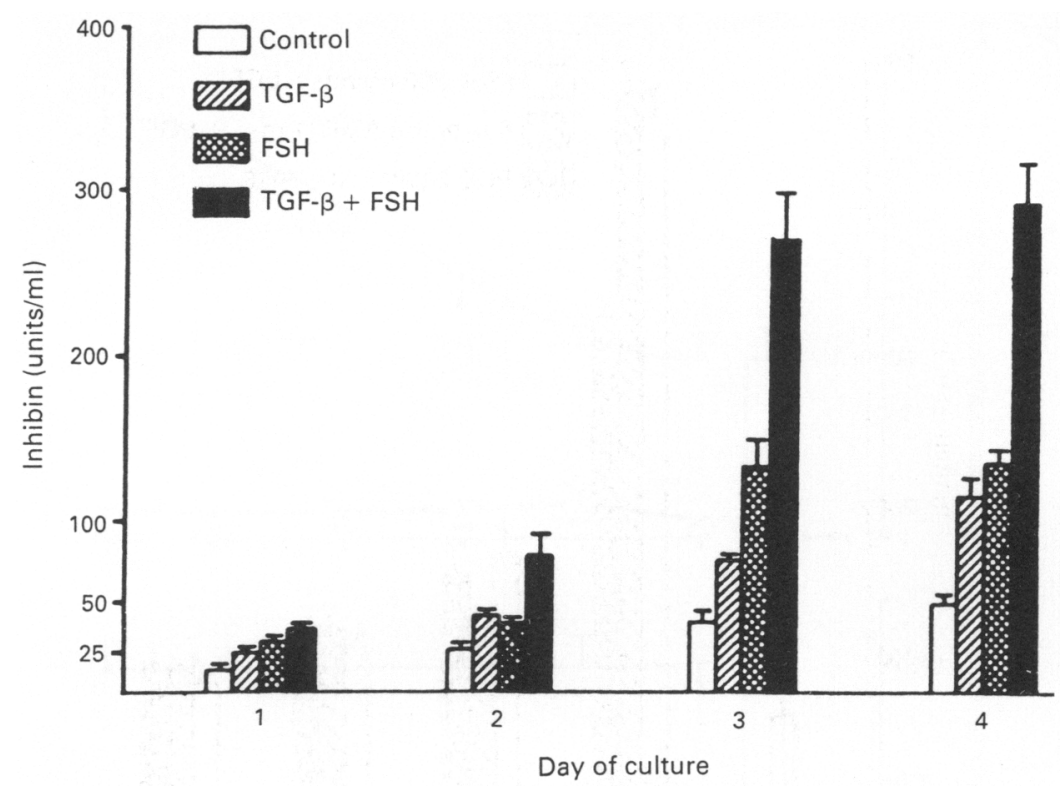

Fig. 4. Effect of TGF- $\beta$ and FSH on inhibin production by rat granulosa cells in vitro. Granulosa cells were isolated from diethylstilboestrol-treated immature rats and cultured for $1-4$ days in medium alone (control) or in the presence of TGF- $\beta(1 \mathrm{ng} / \mathrm{ml}), \mathrm{FSH}(1 \mathrm{ng} / \mathrm{ml})$ or TGF- $\beta$ and FSH together. Values represent the mean \pm s.e. for triplicate determinations. (Reproduced from Zhang et al., 1988.)

This was consistent with earlier demonstrations of EGF-suppressed inhibin secretion by bovine granulosa cells maintained in high concentrations of fetal calf serum (Franchimont $e t$ al., 1986) and rat granulosa cells (Bicsak et al., 1986), although no effects on basal inhibin secretion were reported in the latter studies. These observations indicate that EGF inhibits granulosa cell function at a point subsequent to cAMP formation.

The inhibitory effect of EGF on granulosa cell function is further exemplified by inhibition of FSH-induced adenylate cyclase (Dodson \& Schomberg, 1987), LH receptor activity (Mondschein \& Schomberg, 1981; Knecht \& Catt, 1983a; May et al., 1987) and of FSH-induced aromatase activity (Hsueh et al., 1981; May et al., 1982). These effects are presumably mediated by specific granulosa cell receptors for EGF (Chabot et al., 1986). High levels of EGF receptor activity on granulosa cells during pro-oestrus and oestrus (Mondschein \& Schomberg, 1981) most probably reflect elevated concentrations of FSH in serum at these stages of the oestrous cycle as EGF receptor activity on granulosa cell is increased by exposure to FSH (Feng et al., 1986).

EGF is able to act both directly and indirectly on granulosa cells to modulate differentiated function. EGF at concentrations of $0 \cdot 1-100 \mathrm{ng} / \mathrm{ml}$ inhibited FSH and TGF- $\beta$-induced inhibin secretion. Most evident was complete blockade of the enhancement by TGF- $\beta$ of FSH-induced inhibin productivity (Fig. 6).

\section{Platelet-derived growth factor (PDGF)}

Originally derived from human platelets PDGF was shown to be a potent mitogen for cells of mesenchymal origin (Deuel \& Huang, 1983). Using endogenous ornithine decarboxylase activity as a measure of proliferative activity, the decarboxylase activity in pig granulosa cells could only be stimulated in the presence of a relatively crude platelet extract (Baranao \& Hammond, 1984b). 


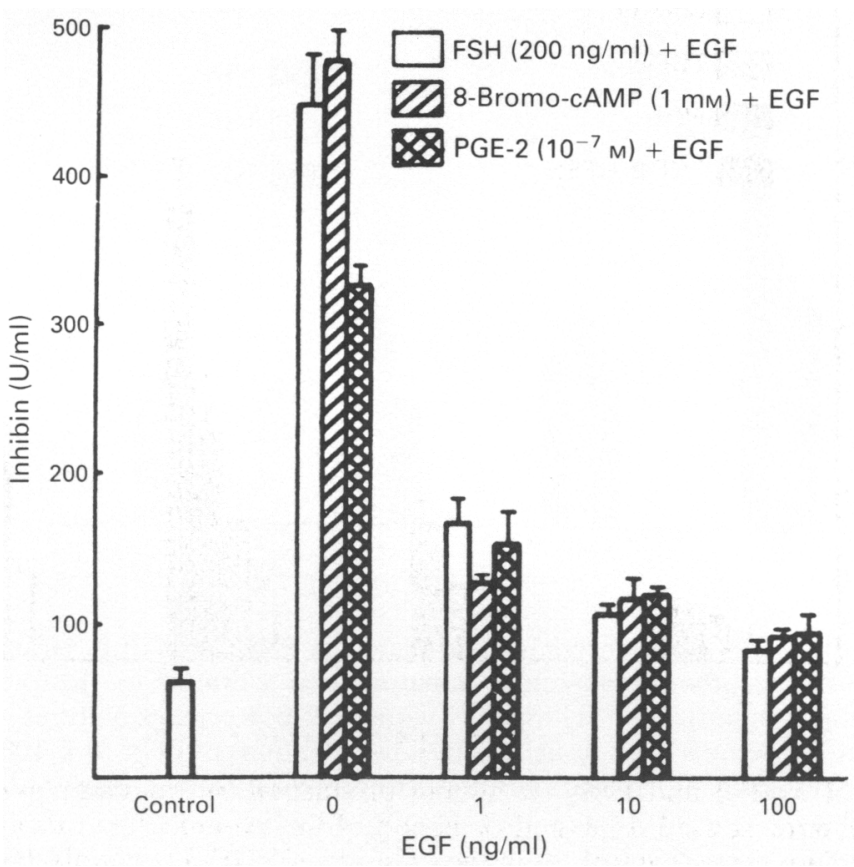

Fig. 5. Effect of EGF on stimulated inhibin production in vitro. Granulosa cells were isolated from diethylstilboestrol-treated immature rats and cultured in medium alone (control), FSH, 8-bromo-cyclic AMP or PGE-2. Replicate cultures were established in the absence of EGF or increasing concentrations of exogenous EGF $(1-100 \mathrm{ng} / \mathrm{ml})$. Values represent the mean \pm s.e. of triplicate determinations. (Reproduced from Zhang et al., 1978a.)

Addition of purified PDGF to these cells was without effect, which implied either that PDGF did not stimulate granulosa cell ornithine decarboxylase activity, or that PDGF action required the presence of other unidentified components of platelet extracts. Purified PDGF was subsequently shown to enhance FSH-induced progesterone secretion by granulosa cells, adenylate cyclase activity (Knecht \& Catt, 1983b) and LH receptor induction (Knecht \& Catt, 1983b; Mondschein \& Schomberg, 1984).

\section{Possible relationship between mitosis and differentiation of granulosa cells}

Although the effects of PDGF and IGF-I on granulosa cell mitosis are uncertain, TGF- $\beta$ inhibits EGF-stimulated proliferation of bovine granulosa cells (Skinner et al., 1987b). In contrast, EGF stimulates proliferation of granulosa cells in vitro (Gospodarowicz et al., 1977; Gospodarowicz \& Bialecki, 1979; Skinner et al., 1987a). These observations, together with the respective positive and negative effects of TGF- $\beta$ and EGF on granulosa cell differentiation, suggest an inverse relationship between mitosis and differentiation of granulosa cells (Fig. 7).

Granulosa cells proliferate in media containing sera but cannot be induced to undergo functional differentiation under these conditions. Differentiation of granulosa cells and maintenance of a differentiated state in vitro is possible only in chemically-defined media which do not support mitosis (Orly et al., 1980; Savion et al., 1981; Erickson, 1983; Epstein-Almog \& Orly, 1985). The postulate that mitosis and differentiation of granulosa cells is related inversely (Chevalier et al., 1981) is further supported by the observations that progesterone synthesis by 


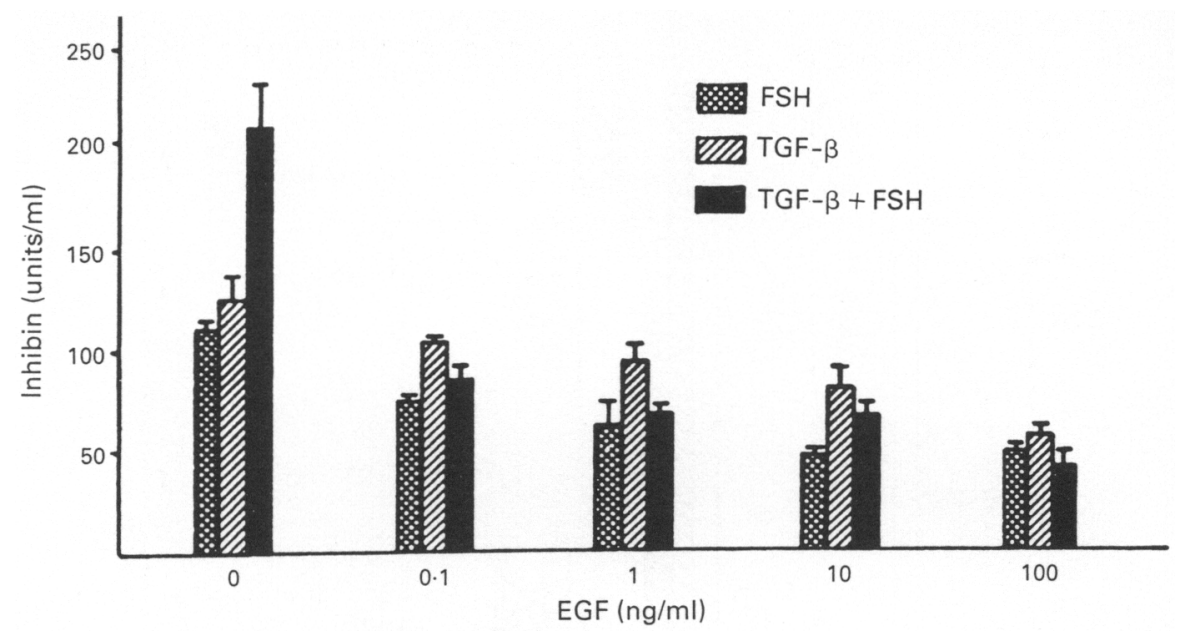

Fig. 6. Effect of EGF on inhibin secretion stimulated by FSH or TGF- $\beta$. Granulosa cells were isolated from diethylstilboestrol-treated immature rats cultured in the presence of FSH $(1 \mathrm{ng} / \mathrm{ml})$, TGF- $\beta(1 \mathrm{ng} / \mathrm{ml})$ and FSH together with TGF- $\beta$. Replicate cultures were established in the absence of exogenous EGF or increasing concentrations of EGF $(0 \cdot 1-100 \mathrm{ng} / \mathrm{ml})$. Values represent the mean \pm s.e. of triplicate cultures. (Reproduced from Zhang et al., 1988.)

Growth factor Mitosis Differentiation

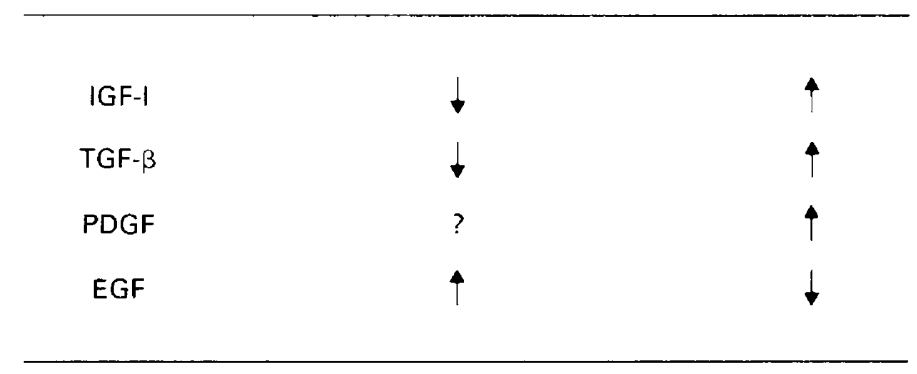

Fig. 7. Summary of the effects of insulin-like growth factor (IGF-I), transforming growth factor-type $\beta$ (TGF- $\beta$ ), platelet-derived growth factor (PDGF) and epidermal growth factor (EGF) on granulosa cell function in vitro. $\uparrow$, Stimulation; $\downarrow$, inhibition; ?, uncertain.

granulosa cells was inversely related to the spontaneous changes in mitotic activity which occurred over a 12-day culture (Epstein-Almog \& Orly, 1985) and to stimulation of pig granulosa cells by theca-derived mitogens (Makris \& Ryan, 1987; Skinner et al., 1987b).

The apparent coincidence of FSH-induced differentiation with the period of maximal mitotic activity of granulosa cells in small and medium-sized antral follicles (Hirshfield \& Midgley, 1978) does not necessarily argue against an inverse relationship between mitosis and differentiation in developing follicles. It is possible that individual granulosa cells enter asynchronously successive periods of mitosis and differentiation when de-differentiation of a cell is mandatory for each mitosis. As an increasing proportion of granulosa cells is prevented from re-entering successive periods of de-differentiation/mitosis, reduced mitotic activity would accompany 'differentiation' of the whole population of granulosa cells.

Thus both proliferation and differentiation would occur in an entire population of granulosa cells while an inverse relationship between mitosis and differentiation was maintained at the cellular 


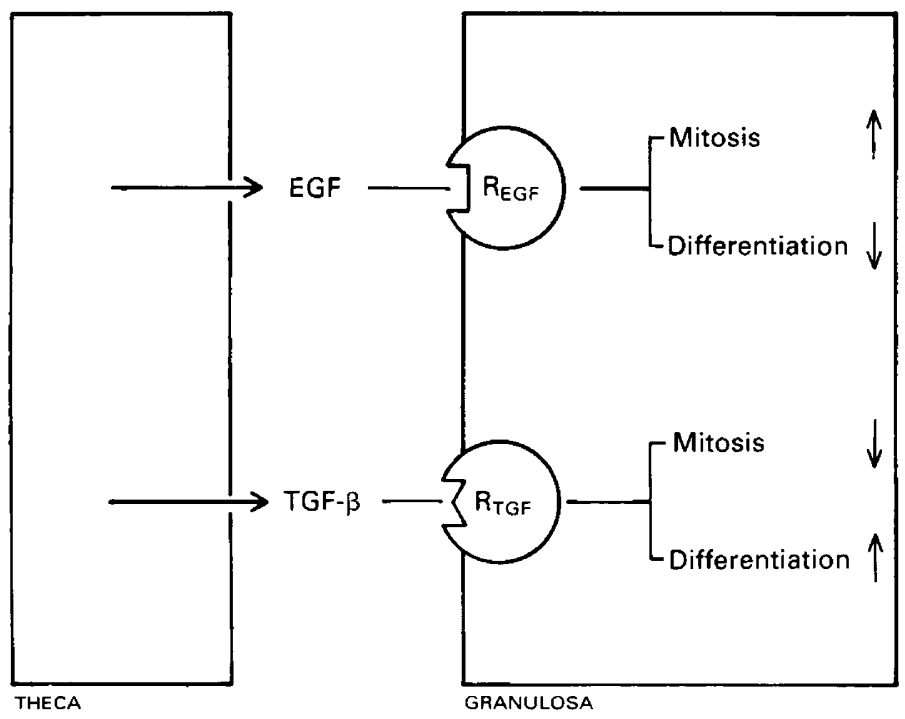

Fig. 8. Putative interaction of theca-derived growth factors with granulosa cells.

level. The antimitotic effect of TGF- $\beta$ (see above) and inhibitors of mitosis present in the antral fluid of large sheep follicles (Carson et al., 1988) would therefore be necessary adjuncts to trophic factors which induce differentiation of follicle cells.

These antimitotic effects are possibly exerted on granulosa cells directly by blocking the mitogenic effects of EGF and follicular oestradiol-17 $\beta$, or by inhibition of thecal EGF activity.

\section{Theca cells as a source of ovarian growth factors}

The demonstration that proliferation in vitro could be stimulated by addition of thecae to cultures of human granulosa cells (McNatty et al., 1980) suggested that the mitogen present in steroid-free pig follicular fluid (Ledwitz-Rigby, 1980) might have been of thecal origin. Stimulation of granulosa cell mitosis by extracts of pig theca (Makris et al., 1983) and culture media conditioned by rat thecae (Lobb et al., 1988) and of sheep pituitary cells by media conditioned by chicken thecae (Tsonis et al., 1988) confirmed the mitogenic action of thecae derived from several species. It is likely that this activity represents an EGF-like molecule identified in rat thecae (Skinner et al., 1987a). On the basis of radioimmunoassay, radioreceptor and biological assay and electrophoretic mobility, rat thecae are also known to secrete TGF- $\beta$ in vitro (Skinner et al., 1987b).

As discussed above, while EGF inhibits differentiation and stimulates mitosis of granulosa cells, TGF- $\beta$ stimulates differentiation and inhibits mitosis. Theca cells are therefore a source of two growth factors capable of modulating granulosa cell proliferation and differentiation (Fig. 8). As such it is likely that theca cells mediate the effect of trophic factors, possibly $\mathrm{LH}$, on follicular development.

\section{Conclusions}

On the basis of changes in steroidogenic activity and secretion of specific proteins in vitro, IGF-I, TGF- $\beta$ and related proteins, and PDGF enhance FSH-induced differentiation of granulosa cells in vitro. EGF is seen generally to be inhibitory of FSH-induced differentiation. For EGF and TGF- $\beta$, 
the effect of each growth factor on granulosa cell proliferation is the opposite of the effect of each on differentiation, suggesting an inverse relationship between differentiation and mitosis of granulosa cells.

Data indicate that the follicular theca cell is a source of EGF activity and of TGF- $\beta$. In that each of these growth factors has opposing effects on the granulosa cell, the theca most probably modulates granulosa cell mitosis and differentiation in vivo.

Proliferation and differentiation of granulosa cells are the essence of ovarian follicular development. Although these processes were thought originally to be controlled primarily by the pituitary gonadotrophins, evidence for direct involvement of intra-follicular growth factors in control of follicular development is overwhelming.

Follicular oestradiol, a major product of differentiated granulosa cells, a potent mitogen in vivo and yet devoid of any mitogenic action in vitro, represents a paradox in this discussion. Studies of the role of growth factors in ovarian function will lead to a more complete understanding of the control of follicular development by intra-follicular growth factors and, perhaps, the role of oestradiol in the growing follicle.

We thank the Society for the Study of Fertility for the invitation to participate in this Symposium and Mrs Faye Coates and Mr Michael Whitehead for assistance in preparation of the manuscript. Financial support was received from the National Health and Medical Research Council of Australia and the Australian Meat and Livestock Research and Development Corporation.

\section{References}

Adashi, E.Y., Resnick, C.E., Svoboda, M.E. \& van Wyk, J.J. (1984) A novel role for somatomedia-C in the cytodifferentiation of ovarian granulosa cells. Endocrinology 155, 1227-1229.

Adashi, E.Y., Resnick, C.E., D'Ercole, A.J., Svoboda, M.E. \& Van Wyk, J.J. (1985a) Insulin-like growth factors as intraovarian regulators of granulosa cell growth and function. Endocrine Reviews 6, 400-420.

Adashi, E.Y., Resnick, C.E., Svoboda, M.E. \& Van Wyk, J.J. (1985b) Somatomedin-C enhances induction of luteinizing hormone receptors by follicle-stimulating hormone in cultured rat granulosa cells. Endocrinology 116, 2369-2375.

Adashi, E.Y., Resnick, C.E., Svoboda, M.E. \& van Wyk, J.J. (1985c) Somatomedin-C synergises with folliclestimulating hormone in the acquisition of progestin biosynthetic capacity by cultured rat granulosa cells. Endocrinology 116, 2135-2142.

Adashi, E.Y., Resnick, C.E., Svoboda, M.E. \& Van Wyk, J.J. (1986a) Somatomedin-C as an amplifier of follicle-stimulating hormone action: enhanced accumulation of adenosine $3^{\prime}, 5^{\prime}$-monophosphate. Endocrinology 118, 149-155.

Adashi, E.Y., Resnick, C.E. \& Svoboda, M.E. (1986b) Follicle-stimulating hormone enhances somatomedin C-binding to cultured rat granulosa cells. Evidence for cAMP dependence. J. biol. Chem. 261, 3923-3926.

Adashi, E.Y., Resnick, C.E., Hernandez, E.R., Svoboda, M.E. \& Van Wyk, J.J. (1988a) Characterization and regulation of a specific cell membrane receptor for somatomedin-C/insulin-like growth factor 1 in cultured rat granulosa cells. Endocrinology 122, 194-201.

Adashi, E.Y., Resnick, C.E., Hernandez, E.R., Svoboda, M.E. \& Van Wyk, J.J. (1988b) In vivo regulation of granulosa cell somatomedin-C/insulin-like growth factor 1 receptors. Endocrinology 122, 1383-1389.

Adashi, E.Y., Resnick, C.E., Hernandez, E.R., May, J.V., Knecht, M., Svoboda, M.E. \& Van Wyk, J.J (1988c) Insulin-like growth factor-1 as an amplifier of folliclestimulating hormone action: studies on mechanism(s) and site(s) of action in cultured rat granulosa cells. Endocrinology 122, 1583-1591.

Baranao, J.L. \& Hammond, J.M. (1984a) Comparative effects of insulin and insulin-like growth factors on DNA synthesis and differentiation of porcine granulosa cells. Biochem. Biophys. Res. Commun. 124, 484490.

Baranao, J.L. \& Hammond, J.M. (1984b) Serum-free medium enhances growth and differentiation of cultured pig granulosa cells. Endocrinology 116, $51-58$.

Bicsak, T.A., Tucker, E.M., Cappel, S., Vaughan, J., Rivier, J., Vale, W. \& Hsueh, A.J.W. (1986) Hormonal regulation of granulosa cell inhibin biosynthesis. Endocrinology 119, 2711-2719.

Burger, H., Zhang, Z., Davis, S., Lee, V., Carson, R., Herington, A., Findlay, J., Farnworth, P., Wang, Q., Au, S., de Kretser, D. \& Robertson, D. (1988) Inhibin-regulation and mechanism of action. In Nonsteroidal Gonadal Factors; Physiological Roles and Possibilities in Contraceptive Development. Eds Z. Rosenvacks \& G. Hodgen (in press). Jones Institute Press, Arlington.

Carson, R.S., Richards, J.S. \& Kahn, L.E. (1981) Functional and morphological differentiation of theca and granulosa cells during pregnancy in the rat: dependence on increased basal luteinizing hormone activity. Endocrinology 109, 1433-1441. 
Carson, R.S., Robertson, D.M. \& Findlay, J.K. (1988) Ovine follicular fluid inhibits thymidine incorporation by 3 T3 fibroblasts in vitro. $J$. Reprod. Fert. 82 , $447-455$.

Chabot, J.G., St-Arnaud, R., Walker, P. \& Pelletier, G. (1986) Distribution of epidermal growth factor receptors in the rat ovary. Molec. cell. Endocr. 44, 99-108.

Chevalier, S., Bleau, G., Roberts, K.D. \& Chapdelaine, A. (1981) Proliferation and differentiation of canine prostate epithelial cells in culture. Molec. cell. Endocr. 24, 195-208.

Davoren, J.B. \& Hsueh, A.J.W. (1986) Growth hormone increases ovarian levels of immunoreactive somatomedin c/insulin-like growth factor 1 in vivo. Endocrinology 118, 888-890.

Davoren, J.B., Kasson, B.G., Li, C.H. \& Hsueh, A.J.W. (1986) Specific insulin-like growth factor (IGF) Iand II-binding sites on rat granulosa cells: relation to IGF action. Endocrinology 119, 2155-2162.

Dodson, W.C. \& Schomberg, D.W. (1987) The effect of transforming growth factor-beta on follicle-stimulating hormone-induced differentiation of cultured rat granulosa. Endocrinology 120, 512-516.

Deuel, T.F. \& Huang, J.S. (1983) Platelet-derived growth factor: purification, properties and biological activities. Progress in Hematology 13, 201-221.

Epstein-Almog, R. \& Orly, J. (1985) Inhibition of hormone-induced steroidogenesis during cell proliferation in serum-free cultures of rat granulosa cells. Endocrinology 116, 2103-2112.

Erickson, G.F. (1983) Primary cultures of ovarian cells in serum-free media as models of hormone-dependent differentiation. Molec. cell. Endocr. 29, 21 49.

Feng, P., Catt, K.J. \& Knecht, M. (1986) Transforming growth factor beta regulates the inhibitory actions of epidermal growth factor during granulosa cell differentiation. J. biol. Chem. 261, 14167-14170.

Franchimont, P., Hazee-Hagelstein, M.T., CharletRenard, Ch. \& Jaspar, J.M. (1986) Effect of mouse epidermal growth factor on DNA and protein synthesis, progesterone and inhibin production by bovine granulosa cells in culture. Acta endocr. Copenh. 111, 122-127.

Gospodarowicz, D. \& Bialecki, H. (1979) Fibroblast and epidermal growth factors are mitogenic agents for cultured granulosa cells of rodent, porcine, and human origin. Endocrinology 104, 757-764.

Gospodarowicz, D., Ill, C.R. \& Birdwell, C.R. (1977) Effects of fibroblast and epidermal growth factors on ovarian cell proliferation in vitro. 1 . Characterization of the response of granulosa cells to FGF and EGF. Endocrinology 100, 1108-1120.

Hammond, J.M., Baranoa, J.L.S., Skaleris, D., Knight, A.B., Ronanus, J.A. \& Rechler, M.M. (1985) Production of insulin like growth factors by ovarian granulosa cells. Endocrinology 117, 2553-2555.

Hernandez, E.R., Twardzik, D.R., Purchio, A. \& Adashi, E.Y. (1987) Gonadotropin-dependent ovarian transforming growth factor- $\beta$ gene expression. Biol. Reprod. 36 (Suppl.) 58, Abstr. 35.

Hernandez, E.R., Resnick, C.E., Sroboda, M.E., Van Wyk, J.J., Payne, D.W. \& Adashi, E.Y. (1988) Somatomedin-C/insulin-like growth factor I as an enhancer of androgen biosynthesis by cultured rat ovarian cells. Endocrinology 122, 1603-1612.
Hirshfield, A.N. \& Midgley, A.R., Jr (1978) Morphometric analysis of follicular development in the rat. Biol. Reprod. 19, 597-605.

Hsu, C. \& Hammond, J.M. (1987) Gonadotropins and estradiol stimulate immunoreactive insulin-like growth factor-I production by porcine cells in vitro. Endocrinology 120, 198-207.

Hsueh, A.J.W., Adashi, E.Y., Jones, P.B.C. \& Welsh, T.H., Jr (1984) Hormonal regulation of the differentiation of cultured ovarian granulosa cells. Endocrine Rev. 5, 76-127.

Hsueh, A.J.W., Welsh, T.H. \& Jones, P.B.C. (1981) Inhibition of ovarian and testicular steroidogenesis by epidermal growth factor. Endocrinology 108, 2002-2004

Hsueh, A.J.W., Dahl, K.D., Vaughan, J., Tucker, E., Rivier, J., Bardin, C.W. \& Vale, W. (1987) Heterodimers and homodimers of inhibin subunits have different pacrine action in the modulation of luteinizing hormone-stimulated androgen biosynthesis. Proc. natn. Acad. Sci. U.S.A. 84, 5082-5086.

Hutchinson, L.A., Findlay, J.K., de Vos, F.L. \& Robertson, D.M. (1987) Effects of bovine inhibin, transforming growth factor-beta and bovine ActivinA on granulosa cell differentiation. Biochem. Biophys. Res. Commun. 146, 1405-1412.

Knecht, M. \& Catt, K. (1983a) Epidermal growth factor and gonadotropin-releasing hormone inhibit cyclic AMP-dependent luteinizing hormone receptor formation in ovarian granulosa cells. $J$. Cell Biochem. 21, 209-217.

Knecht, M. \& Catt, K.J. (1983b) Modulation of cAMPmediated differentiation in ovarian granulosa cells by epidermal growth factor and platelet-derived growth factor. J. biol. Chem. 258, 2789-2794.

Knecht, M., Feng, P. \& Catt, K.J. (1986) Transforming growth factor-beta regulates the expression of luteinizing hormone receptors in ovarian granulosa cells. Biochem. Biophys. Res. Commun. 139, 800-807.

Ledwitz-Rigby, F. (1980) Reversal of follicular inhibition of granulosa cell progesterone secretion by manipulation of intracellular cAMP. Biol. Reprod. 23, $324-333$.

Lobb, D.K., Skinner, M.K. \& Dorrington, J.H. (1988) Rat thecal/interstitial cells produce a mitogenic activity that promotes the growth of granulosa cells. Molec. cell. Endocr. 55, 209-217.

McNatty, K.P., Makris, A., DiGrazia, D., Osathanondh, R. \& Ryan, K.J. (1980) Steroidogenesis by recombined follicular cells from the human ovary in vitro. J. clin. Endocr. Metab. 51, 1286-1289.

Makris, A. \& Ryan, K.J. (1987) Effect of ovarian growth factor (OGF) and gonadotropins on progesterone synthesis (P) and growth of porcine granulosa cell. Biol. Reprod. 36 (Suppl.), 90 Abstr. 132.

Makris, A., Klagsbrun, M.A., Yasumizu, T. \& Ryan, K.J. (1983) An endogenous ovarian growth factor which stimulates BALB/3T3 and granulosa cell proliferation. Biol. Reprod. 29, 1135-1141.

Mason, A.J., Hayflick, J.S., Ling, N., Esch, F., Ueno, N., Ying, S.Y., Guillemin, R., Niall, H. \& Seeburg, P.H. (1985) Complementary DNA sequences of ovarian follicular fluid inhibin show precursor structure and homology with transforming growth factor- $\beta$. Nature, Lond. 318, 659-663. 
May, J.V., Gilliam, F.R., Rein, M.S., Mondschein, J.S. \& Schomberg, D.W. (1982) Mondayer growth and differentiated functions of porcine and rat granulosa cells following cryopreservation. Biol. Reprod. 27, 641-651.

May, J.V., Buck, P.A. \& Schomberg, D.W. (1987) Epidermal growth factor enhances [1251]iodo-folliclestimulating hormone binding by cultured porcine granulosa cells. Endocrinology 120, 2413-2420.

McLachlan, R.I., Robertson, D.M., Burger, H.G. \& de Kretser, D.M. (1986) The radioimmunoassay of bovine and human follicular fluid and serum inhibin. Molec. cell. Endocr. 46, 175-185.

Mondschein, J.S. \& Schomberg, D.W. (1981) Growth factors modulate gonadotropin receptor induction in granulosa cell cultures. Science, N.Y. 211, 1179-1180.

Mondschein, J.S. \& Schomberg, D.W. (1984) Effects of partially and more highly purified platelet-derived growth factor preparations on luteinizing hormone receptor induction in granulosa cell cultures. Biol. Reprod. 30, 603 608 .

Moses, H.L., Tucker, R.F., Leof, E.B., Coffey, R.J., Halper, J. \& Shipley, G.D. (1985) Type beta transforming growth factor is a growth stimulator and a growth inhibitor. Cancer Cells (Cold Spring Harbor) 3, 65-71.

Orly, J., Sato, G. \& Erikson, G.F. (1980) Serum suppresses expression of hormonally induced function in cultured granulosa cells. Cell 20, 817-827.

Richards, J.S. (1975) Content of nuclear estradiol receptor complex in rat granulosa cells during follicular development: modification by estradiol and gonadotropins. Endocrinology 97, 1174-1184.

Richards, J.S., Ireland, J.J., Rao, M.C., Bernath, G.A., Midgley, A.R., Jr \& Reichert, L.E., Jr (1976) Ovarian Follicular Development in the rat: hormone receptor regulation by estradiol, follicle stimulating hormone and luteinizing hormone. Endocrinology 99, 1562-1570.

Savion, N., Lui, G., Laherty, R. \& Gospodarowicz, D. (1981) Factors controlling proliferation and progesterone production by bovine granulosa cells in serum-free medium. Endocrinology 109, 409-420.

Schams, D., Koll, R. \& Li, C.H. (1988) Insulin-like growth factor-I stimulates oxytocin and progesterone production by bovine granulosa cells in culture. $J$. Endocr. 116, 97-100.

Skinner, M.K., Keski-Oja, J., Osteen, K.G. \& Moses, H.L. (1987a) Ovarian thecal cells produce transform- ing growth factor- $\beta$ which can regulate granulosa cell growth. Endocrinology 121, 786-792.

Skinner, M.K., Lobb, D. \& Dorrington, J.H. (1987b) Ovarian thecal/interstitial cells produce an epidermal growth factor-like substance. Endocrinology 121, 1892-1899.

Tsonis, C.G. \& Sharpe, R.M. (1986) Dual gonadal control of follicle-stimulating hormone. Nature, Lond. 321, 724-725.

Tsonis, C.G., Sharp, P.J. \& McNeilly, A.S. (1988) Inhibin bioactivity and pituitary cell mitogenic activity from cultured chicken ovarian granulosa and thecal/ stromal cells. J. Endocr. 116, 293-299.

Veldhuis, J.D. \& Rodgers, R.J. (1987) Mechanisms subserving the steroidogenic synergism between folliclestimulating hormone and insulin-like growth factor I (somatomedin C). Alterations in cellular sterol metabolism in swine granulosa cells. J. biol. Chem. 262, 7658-7664.

Veldhuis, J.D., Rodgers, R.J., Dee, A. \& Simpson, E.R. (1986) The insulin-like growth factor, somatomedin $C$, induces the synthesis of cholesterol side-chain cleavage cytochrome $\mathrm{P}-450$ and adrenodoxin in ovarian cells. J. biol. Chem. 261, 2499-2502.

Veldhuis, J.D., Nestler, J.E. \& Strauss, J.F. (1987) The insulin-like growth factor, somatomedin-C, modulates low density lipoprotein metabolism by swine granulosa cells. Endocrinology 121, 340-346.

Ying, S.T., Becker, A., Ling, N., Ueno, N. \& Guillemin, R. (1986) Inhibin and beta type transforming growth factor (TGF $\beta$ ) have opposite modulating effects on the follicle stimulating hormone (FSH)-induced aromatase activity of cultured rat granulosa cells. Biochem. Biophys. Res. Commun. 136, 969-975.

Zhang, Z., Herington, A.C., Carson, R.S., Findlay, J.K. \& Burger, H.G. (1987a) Direct inhibition of rat granulosa cell inhibin production by epidermal growth factor in vitro. Molec. cell. Endocr. 54, 213-220.

Zhang, Z.W., Carson, R.S., Herington, A.C., Lee, V.W. \& Burger, H.G. (1987b) Follicle-stimulating hormone and somatomedin-C stimulate inhibin production by rat granulosa cells in vitro. Endocrinology 120 , $1633-1638$.

Zhang, Z., Findlay, J.K., Carson, R.S., Herington, A.C.H. \& Burger, H.G. (1988) Transforming growth factor $\beta$ enhances basal and FSH stimulated inhibin production by rat granulosa cells in vitro. Molec. cell. Endocr. 58, 161-166. 